\title{
Clinical manifestation of HIV/AIDS patients: differences between public and private hospitals in Jakarta
}

\author{
Herdiman T Pohan
}

\begin{abstract}
Abstrak
Tujuan penelitian ini adalah untuk menentukan data demografi, faktor risiko, gambaran klinis, infeksi oportunis/ko-infeksi dan perbedaannya pada rumah sakit pemerintah dan swasta. Penelitian retrospektif-deskriptif dilakukan di RSUPN-Dr. Cipto Mangunkusumo (RS pemerintah) dan RS Medistra (RS swasta) di Jakarta. Kriteria inklusi mencakup kasus HIV/AIDS yang dirawat pada tahun 2002-2003, dan hasil serologi HIV positif dengan metode Elisa. Data sekunder didapatkan dari rekam medis. Enam puluh enam subyek diikut-sertakan dalam penelitian (RS pemerintah 30 subyek dan RS swasta 36 subyek), terdiri dari 59 pria (89.4\%) dan 7 wanita (10.6\%). Tiga puluh tujuh persen subyek didiagnosis HIV dan $62 \%$ AIDS. Faktor risiko yang didapat mencakup pengguna narkoba (59.1\%), homoseksual (13.6\%), heteroseksual (21.1\%), transfusi (1.5\%) dan perinatal (1.5\%). Gejala klinis terutama berupa demam akut (56.2\%), penurunan berat badan (39.4\%), batuk (38.8\%), sesak nafas (27.2\%), diare kronik (22.8\%), demam berkepanjangan (19.7\%), penurunan kesadaran (15.3\% dan, anoreksia (15.3\%). Perbedaan bermakna antara RS pemerintah dan swasta didapatkan pada keluhan demam dan batuk. Presentasi klinis pasien HIV/AIDS selama perawatan mencakup : pnemonia $(56 \%)$, oral trush (22.6\%), anemia (56.5\%), lekopenia (32.3\%), limfopenia (55.9\%), peningkatan SGOT/SGPT (66.1\%), hipoalbuminemia (46.9\%), limfadenopati (10.6\%), lesi serebral $(7.6 \%)$, ensefalopati $(6.0 \%)$, tuberkulosis paru dan efusi pleura (10.6\%). Infeksi oportunis dan ko-infeksi mencakup kandidosis (25.8\%), hepatitis C kronik (24.2\%), hepatitis B dan C kronik (4.5\%), tb paru, limfadenitis dan tb milier. Kandidosis dan tb paru lebih sering ditemukan di RS pemerintah. Kesimpulan dari penelitian ini bahwa manifestasi klinis HIV/AIDS berupa pria/wanita usia muda dengan satu atau lebih faktor risiko, mengalami demam, keluhan pernapasan, penurunan berat badan, diare kronik, lemah, oral trush, anemia, lekopenia, limfopenia. Pasien yang dirawat di RS swasta menunjukkan gejala yang lebih bervariasi sedangkan yang dirawat di RS pemerintah menunjukkan kondisi yang lebih berat dan stadium lebih lanjut. (Med J Indones 2004; 13: 232-6)
\end{abstract}

\begin{abstract}
The aims of this study is to determine the demographic data, risk factors, clinical presentations, opportunistic/co-infections and its difference between public and private hospitals. A retrospective-descriptive study was conducted in Dr. Cipto Mangunkusumo National General Hospital (public hospital) and Medistra Hospital (private hospital), Jakarta. The inclusion criteria were new HIV/AIDS cases admitted in year 2002-2003 and positive HIV serology (Elisa method). Secondary data were collected form medical record. Sixty-six subjects were enrolled in this study (public hospital 30 subjects and private hospital 36 subjects), consist of 59 male (89.4\%) and 7 female (10.6\%). Thirty-seven percent subjects were defined as HIV and 62\% AIDS. Risk factors obtained include drug user (59.1\%), homosexual (13.6\%), heterosexual (21.1\%), transfusion (1.5\%) and maternal-child (perinatal) (1.5\%). The clinical symptoms mainly present as acute fever (56.2\%), weight loss (39.4\%), cough (38.8\%), shortness of breath (27.2\%), chronic diarrhea (22.8\%), prolong fever (19.7\%), loss of conciousness (15.3\%), anorexia (15.3\%). Significant differences between public and private hospitals were seen in fever and cough symptoms. Clinical presentation of HIV/AIDS patients during admission were : pneumonia (56\%), oral trush (22.6\%), anemia (56.5\%), leucopenia (32.3\%), lymphopenia (55.9\%), elevated AST/ALT (66.1\%), hypoalbuminemia (46.9\%), limphadenopathy (10.6\%), brain space occuping lesion (7.6\%), encephalopathy (6.0\%), pulmonary tb and pleural effusion (10.6\%). The opportunistic and co-infections present were candidiasis $(25.8 \%)$, chronic hepatitis $C(24.2 \%)$, chronic hepatitis $B$ and $C(4.5 \%)$, pulmonary $t b$, lymphadenitis and miliary tb. Candidiasis and pulmonary tb were frequently found in public hospital. In conclusion from this study that clinical manifestation of HIV/AIDS were young man or woman, with one or more possible risk factor, had fever, respiratory complain, loss of body weight, chronic diarrhea, fatique, oral trush, anemia, leucopenia, lymphopenia. Patients admitted in private hospital had varied complain; and patients that admitted in public hospital had more severe and advance condition. (Med J Indones 2004; 13: 232-6)
\end{abstract}

Keywords : HIV, AIDS, Clinical Manifestation

Division of Tropical Medicine and Infectious Diseases, Department of Internal Medicine,

Medical Faculty University of Indonesia/Dr. Cipto Mangunkusumo National General Hospital, Jakarta, Indonesia 
Since first HIV cases were reported in Indonesia in 1987, the number of HIV/AIDS cases tends to increase every year. The cumulative number of HIV/AIDS until March 2004 were 4.159 cases; with 355 of new cases in year 2003. ${ }^{1}$ This number of cases was still under estimate because approximately 80.000 to 120.000 people had infected by year $2002 .^{2}$

The problem in finding the new cases is that the minimal or asymptomatic clinical presentation during the HIV stage. The clinical symptoms of AIDS usually manifest because of secondary or opportunistic infection during the advance stage. It is important for clinician especially in primary care facilities to recognize and diagnose HIV/AIDS in initial stage, because early recognition and treatment of antiretroviral drugs can suppress the viral replication and slow the progress to AIDS.,

The clinical presentation of HIV/AIDS patients find in the public and private care facilities could be differed, because of socio-economic factors. The HIV/AIDS patients who came to private hospitals usually from middle-up in socio-economic status and in earlier stage, but on the contrary in public hospitals. In this study we will describe the demographic data, risk factors, initial medical complains that seek the HIV/AIDS patients to hospitals, clinical presentations, opportunistic/co-infections and its difference between public and private hospitals.

\section{METHOD}

A retrospective-descriptive study was conducted in Dr. Cipto Mangunkusumo National General Hospital (public hospital) and Medistra Hospital (private hospital), Jakarta. The inclusion criteria were new HIV/AIDS cases admitted in year 2002-2003 and positive HIV serology (Elisa method). Secondary data were collected form medical record. Demographic data include: age, sex, nationality; risk factors, clinical symptoms, diagnosis and opportunistic/co-infections were recorded. Categorical data were presented as proportion and percentage, numerical data as mean, median and standard deviation. AIDS patients are defined according to case definition of AIDS in adults 1997. ${ }^{5}$ Chi-square and Mann-Whitney tests were used to differ between groups and significant difference was defined if $\mathrm{p}<0.05$.

\section{RESUTS}

Sixty-six subjects were enrolled in this study, consist of 59 male $(89.4 \%)$ and 7 female $(10.6 \%)$. The youngest age was 7 years old and the oldest was 55 years old (mean 29.7 SD 9.9 years). Thirty-seven percent subjects were defined as HIV and 62\% AIDS. Eightythree percent subjects are Indonesian and $16.7 \%$ are foreign. Risk factors obtained include drug user (59.1\%), homosexual (13.6\%), heterosexual (21.1\%), transfusion (1.5\%) and maternal-child (perinatal) (1.5\%). Mortality of HIV patients are $32 \%$ and AIDS $34.1 \%$.

There were 30 subjects from public hospital and 36 subjects from private hospital. Subject from public hospital were younger than private hospital (mean of age was 27.9 vs 38.1 years $p<0.05$ ). Significant differences was also seen on nationality and risk factors. Drug user is the most frequent risk factor in public hospital, but in private hospital drug user as well as homo or heterosexual seem to be the common risk factors . (Table 1)

Table 1. Subjects Characteristics

\begin{tabular}{|c|c|c|c|}
\hline & $\begin{array}{l}\text { Public Hosp } \\
\qquad(\mathrm{n}=30) \\
\mathrm{n}(\%)\end{array}$ & $\begin{array}{c}\text { Priv Hosp } \\
(\mathrm{n}=36) \\
\mathrm{n}(\%)\end{array}$ & $\begin{array}{c}\text { All } \\
(\mathrm{n}=66) \\
\mathrm{n}(\%)\end{array}$ \\
\hline \multicolumn{4}{|l|}{ Age $^{*}$} \\
\hline$\leq 20$ & $7(23.3)$ & $4(11.1)$ & $11(16.6)$ \\
\hline$\overline{21}-30$ & $15(50.0)$ & $15(41.6)$ & $30(45.4)$ \\
\hline $31-40$ & $6(20.0)$ & $8(22.2)$ & $14(21.1)$ \\
\hline $41-50$ & $2(6.6)$ & $4(11.1)$ & $6(9.1)$ \\
\hline$\geq 51$ & 0 & $5(13.8)$ & $5(7.6)$ \\
\hline \multicolumn{4}{|l|}{ Sex } \\
\hline Male & $26(86.6)$ & $33(91.6)$ & $59(89.4)$ \\
\hline Female & $4(13.3)$ & $3(8.3)$ & 7 (10.6) \\
\hline \multicolumn{4}{|l|}{ Nationality** } \\
\hline Indonesia & $30(100.0)$ & $25(69.4)$ & $55(83.3)$ \\
\hline Foreign & 0 & $11(30.6)$ & $11(16.7)$ \\
\hline \multicolumn{4}{|l|}{ Risk factors $* *$} \\
\hline Drug user & $24(80.0)$ & $13(36.1)$ & $39(59.1)$ \\
\hline Homosexual & $1(3.3)$ & $7(19.4)$ & $9(13.6)$ \\
\hline Heterosexual & $2(6.6)$ & $11(30.6)$ & $14(21.2)$ \\
\hline Transfusion & 0 & $1(2.7)$ & $1(1.5)$ \\
\hline Maternal-child & 0 & $1(2.7)$ & $1(1.5)$ \\
\hline Drug, homosexual & 0 & $1(2.7)$ & $1(1.5)$ \\
\hline Drug, heterosexual & 0 & $1(2.7)$ & $1(1.5)$ \\
\hline Unknown & $2(6.6)$ & $1(2.7)$ & $3(4.6)$ \\
\hline \multicolumn{4}{|l|}{ Case Definition } \\
\hline HIV & $9(30.0)$ & $16(44.4)$ & $25(37.8)$ \\
\hline AIDS & $21(70.0)$ & $20(55.5)$ & $41(62.2)$ \\
\hline \multicolumn{4}{|c|}{ Mortality during admission } \\
\hline HIV & $4(44.4)$ & $4(25.0)$ & $8(32.0)$ \\
\hline AIDS & $7(33.3)$ & $7(35.0)$ & $14(34.1)$ \\
\hline
\end{tabular}


Fever, shortness of breath, diarrhea, loss of consciousness and cough were the most frequent chief complain during admission in both public and private hospitals. Other complains present were fatigue, nausea, abdominal pain, loss of body weight, neck lump, dysphagia, headache, etc. (Table 2)

Table 2. Chief complaint of HIV/AIDS patients

\begin{tabular}{lccc}
\hline & $\begin{array}{c}\text { Public Hosp } \\
(\mathrm{n}=30) \\
\mathrm{n}(\%)\end{array}$ & $\begin{array}{c}\text { Priv Hosp } \\
(\mathrm{n}=36)\end{array}$ & $\begin{array}{c}\text { All } \\
\mathrm{n}(\mathrm{n}=66)\end{array}$ \\
$\mathrm{n}(\%)$
\end{tabular}

The clinical symptoms of HIV/AIDS patients were acute fever $(56.2 \%)$, weight loss (39.4\%), cough $(38.8 \%)$, shortness of breath $(27.2 \%)$, chronic diarrhea $(22.8 \%)$, prolong fever $(19.7 \%)$, loss of conciousness $(15.3 \%)$, anorexia (15.3\%), fatique $(4.5 \%)$ and acute diarrhea $(3.0 \%)$. Significant differences between public and private hospitals were seen in fever and cough symptoms. (Table 3 )

Table 3. Clinical Symptom of of HIV/AIDS Patients during Admission

\begin{tabular}{lccc}
\hline & $\begin{array}{c}\text { Public Hosp } \\
(\mathrm{n}=30) \\
\mathrm{n}(\%)\end{array}$ & $\begin{array}{c}\text { Priv Hosp } \\
(\mathrm{n}=36) \\
\mathrm{n}(\%)\end{array}$ & $\begin{array}{c}\text { All } \\
(\mathrm{n}=66) \\
\mathrm{n}(\%)\end{array}$ \\
\hline Acute fever* (<2 weeks) & $23(76.6)$ & $14(38.8)$ & $37(56.2)$ \\
Weight loss & $12(40.0)$ & $14(38.8)$ & $26(39.4)$ \\
Cough* & $19(63.3)$ & $7(19.4)$ & $26(38.8)$ \\
Shortness of breath & $11(36.7)$ & $7(19.4)$ & $18(27.2)$ \\
Chronic diarrhea & $10(33.3)$ & $5(13.8)$ & $15(22.8)$ \\
Prolong fever (>2weeks) & $4(13.3)$ & $9(25.0)$ & $13(19.7)$ \\
Loss of conciousness & $5(16.7)$ & $5(13.8)$ & $10(15.3)$ \\
Anorexia & $7(23.3)$ & $3(8.3)$ & $10(15.3)$ \\
Fatique & $2(6.6)$ & $1(2.7)$ & $3(4.5)$ \\
Acute diarrhea & $2(6.6)$ & 0 & $2(3.0)$ \\
\hline
\end{tabular}

* Chi-squre test $\mathrm{p}<0.05$
Clinical presentation of HIV/AIDS patients during admission were : pneumonia (56\%), oral trush (22.6\%), anemia $(56.5 \%)$, leucopenia $(32.3 \%)$, lymphopenia (55.9\%), elevated AST/ALT (66.1\%), hypoalbuminemia (46.9\%), limphadenopathy $(10.6 \%)$, brain space occuping lesion single and multiple (7.6\%), encephalopathy $(6.0 \%)$, pulmonary tb and pleural effusion (10.6\%). Differences between public and private hospitals were seen in pneumonia, infective endocarditis, brain lesion, oral trush, pulmonary tb, anemia, elevated ALT/AST and lymphopenia. (Table 4)

Table 4. Clinical Presentation of HIV/AIDS Patients during Admission

\begin{tabular}{|c|c|c|c|}
\hline & $\begin{array}{c}\text { Public Hosp } \\
\quad(\mathrm{n}=30) \\
\mathrm{n}(\%)\end{array}$ & $\begin{array}{l}\text { Priv Hosp } \\
(\mathrm{n}=36) \\
\mathrm{n}(\%)\end{array}$ & $\begin{array}{c}\text { All } \\
(\mathrm{n}=66) \\
\mathrm{n}(\%)\end{array}$ \\
\hline Pneumonia* & $23(76.6)$ & $14(38.8)$ & $37(56.0)$ \\
\hline Infective endocarditis* & $8(26.6)$ & $3(8.3)$ & $11(16.6)$ \\
\hline Single Brain lesion & 0 & $3(8.3)$ & $3(4.5)$ \\
\hline Multiple Brain lesion & 0 & $2(5.6)$ & $2(3.0)$ \\
\hline Encephalopathy & $3(10.0)$ & $1(2.7)$ & $6(6.0)$ \\
\hline Limfoma malignum & 0 & $1(2.7)$ & $1(1.5)$ \\
\hline Lymphadenopathy & $5(16.7)$ & $2(5.6)$ & $7(10.6)$ \\
\hline Oral trush * & $12(40.0)$ & $3(8.3)$ & $15(22.6)$ \\
\hline Esophagitis & 0 & $2(5.6)$ & $2(3.0)$ \\
\hline Pleural effusion & $4(13.3)$ & $3(8.3)$ & $7(10.6)$ \\
\hline Pulmonary tb* & $7(23.3)$ & 0 & $7(10.6)$ \\
\hline Anemia* & $23(76.6)$ & $12^{\xi}(37.5)$ & $35^{\psi}(56.5$ \\
\hline Leucopenia & $13(43.3)$ & $7^{\xi}(21.9)$ & $20^{\psi}(32.3$ \\
\hline Leucositosis & $9(30.0)$ & $8^{\xi}(25.0)$ & $17^{\Psi}(27.4)$ \\
\hline Lymphopenia $(<1000) *$ & $15^{\pi}(71.4)$ & $4^{\theta}(44.4)$ & $19^{\rho}(55.9)$ \\
\hline Thrombocytopenia & $9(30.0)$ & $7^{\mu}(23.3)$ & $16^{\varphi}(26.7)$ \\
\hline Elevated ALT/AST* & $20^{\omega}(83.3)$ & $17^{\xi}(30.4)$ & $37^{\tau}(66.1)$ \\
\hline Hypoalbuminemia & ND & $15^{\xi}(46.9)$ & $15^{\xi}(46.9)$ \\
\hline
\end{tabular}

The opportunistic and co-infections present were candidiasis (25.8\%), chronic hepatitis C (24.2\%), chronic hepatitis $\mathrm{B}$ and $\mathrm{C}(4.5 \%)$, pulmonary tb, lymphadenitis and miliary tb. Candidiasis and pulmonary tb were frequently found in public hospital. (Table 5) 
Table 5. Distribution of opportunistic or co-infection in HIV/AIDS

\begin{tabular}{lccc}
\hline & $\begin{array}{c}\text { Public Hosp } \\
(\mathbf{n = 3 0}) \\
\mathbf{n}(\boldsymbol{\%})\end{array}$ & $\begin{array}{c}\text { Priv Hosp } \\
(\mathbf{n = 3 6 )} \\
\mathbf{n}(\boldsymbol{\%})\end{array}$ & $\begin{array}{c}\text { All } \\
(\mathbf{n = 6 6 )} \\
\mathbf{n}(\boldsymbol{\%})\end{array}$ \\
\hline Candidiasis* & $12(40.0)$ & $5(13.9)$ & $17(25.8)$ \\
Pulmonary tb* & $7(23.3)$ & 0 & $7(10.6)$ \\
Lymphadenitis tb & 0 & $1(2.7)$ & $1(1.5)$ \\
Miliary tb & $1(3.3)$ & 0 & $1(1.5)$ \\
Chronic Hepatitis C & $14(46.6)$ & $2(5.6)$ & $16(24.2)$ \\
Chronic Hepatitis B & $1(3.3)$ & $2(5.6)$ & $3(4.5)$ \\
$\quad$ and C & & & \\
Typhoid fever & 0 & $1(2.7)$ & $1(1.5)$ \\
Malaria & 0 & $2(5.6)$ & $2(3.0)$ \\
\hline
\end{tabular}

Chi-square test $\mathrm{p}<0.05$

\section{DISCUSSION}

Data from this study showed that subjects who suffer from HIV/AIDS were mostly young adults (mean age was 29.7 years). Subjects who admitted in public hospital were relatively younger than in private hospital (mean 27.9 vs 38.1 years). This condition because of many subjects who used intravenous (iv) drugs are in young age. The youngest subject recorded was 7 years old young girl with failure to thrive who suffered from HIV due to perinatal transmission. National data from Ministry of Health Indonesia also showed that HIV/AIDS infection mostly from 20-40 years old population group. ${ }^{6}$

The male subjects seem more than female subjects. It was possibly due to high HIV transmission among iv drug user, heterosexual and homosexual who predominantly was male. Data from iv drug users surveillance in Jakarta in year 2002, showed that $90 \%$ iv drug users were young male $(95 \%$ respondents were below 30 years old). Fifty-six percent of male respondents and $36 \%$ of female used their syringe together with friends. This factor contributed of increasing the risk of transmission HIV infection. ${ }^{7}$

Sixty-two percent of subject was classified as AIDS, whether $38 \%$ was HIV. This sum was higher in public hospital where 70\% were AIDS and 30\% HIV. This data consider that patient who came to public hospitals seems in more advance stage than in private hospital. The mortality in public hospital also higher possibly due to this reason.
The clinical symptoms present in HIV/AIDS patients possibly due HIV symptoms it self, or manifestation of opportunistic and co-infections. The most clinical complain and symptoms were fever related to respiratory symptoms where pneumonia was mostly diagnosed. Pneumonia possibly due to typical or atypical bacteria, fungal and mycobacteria. About $16 \%$ subjects suffered from infective endocarditis related to septic iv infections. Pleural effusion in some subjects related to pleural infection of tuberculosis or other bacteria. Hematological disorders like anemia, leucopenia, lymphopenia were possibly due to chronic illness, HIV infection and co-infection with hepatitis $\mathrm{C}$ virus.

Comparing our data to formerly clinical epidemiologic study that conducted in 1995-1996, showed that age, clinical symptoms (prolong fever, cough, loss of body weight, diarrhea, shortness of breath, limphadenopathy, loss of conciousness, encephalopathy) and opportunistic infections (candidiasis, pneumonia and tuberculosis) had the same pattern with our study. Differences were noted that homosexual and heterosexual were the most common risk factors above drug user. ${ }^{8}$

Opportunistic infections in HIV patients was related to decreased of CD4 T cell count. ${ }^{9,10}$ In our study, Candidia infection found in $25 \%$ subjects which manifest as oral and esophageal candidiasis. Candida infections are common if $\mathrm{CD} 4 \mathrm{~T}$ cell below $500 / \mathrm{mm}^{3}{ }^{11}$

Tuberculosis infection was found in $13 \%$ subjects and manifest as pulmonary tb (10\%), lymphadenitis $(1.5 \%)$ and miliary tb (1.5\%). Clinical presentation of pulmonary tb in patients with advance HIV whose CD4 $\mathrm{T}$ cell count are very low could be atypical. Tuberculosis could presented as pneumonia, miliary or extrapulmonary manifestation. ${ }^{12}$ Mycobacterium atypic are other possible cause except Mycobacterium tuberculosis. Diagnosis of this pathogen are difficult and not routinely performed in our hospital.

Toxoplasmosis is one possible cause of CNS manifestation in HIV patients. We found 5 cases of cerebral lesion, 2 of them are multiple and suspected as cerebral toxoplasmosis. One cases of single brain lesion caused by malignant lymphoma. Another caused of cerebral lesion in HIV patients could be fungal infection (cryptococcal) and CMV. ${ }^{13}$ 


\section{CONCLUSIONS}

We found from this study that clinical manifestation of HIV/AIDS patients present as: young man or woman, with one or more possible risk factor, had fever, respiratory complain (shortness of breath, cough), loss of body weight, chronic diarrhea, fatique, oral trush, anemia, leucopenia, lymphopenia.

Patients admitted in private hospital had varied complain than in public hospital and patients that admitted in public hospital had more severe and advance condition than in public hospital. Pneumonia, infective endocarditis, pulmonary tuberculosis, anemia, elevated AST/ALT and candidiasis found in public hospital more than in private hospital.

\section{Acknowledgement}

We thank Prof. Dr. Zubairi Djoerban for his support in our study.

\section{REFERENCES}

1. Ministry of Health Indonesia, Directorate General of Communicate Diseases Control and Environment Health. Statistic of HIV/AIDS in Indonesia. Jakarta 2004.

2. World Health Organization Western Pacific-South East Asia. HIV/AIDS in Asia and the Pacific Region 2003. World Health Organization; 2004. p. 59-62.

3. Palella FJ, Delaney KN, Moorman AC, Loveless MO, Fuhrer J, Satten GA, et al. Declining morbidity and mortality among patients with advance Human
Immunodeficiency Virus Infection. N Eng J Med 1999;38(13)853-60.

4. Gulick RM, Mellors JW, Havlir D, Erron JJ, Meibohm A, Condra JH, et al. 3 year suppression of HIV viremia with indinavir, zidovudin and lamivudin. Ann Intern Med 2000;133:35-9.

5. Bartlet JG, Gallant JE. Medical management of HIV infection. Maryland: Johns Hopkins University, Division of Infectious Diseases; 2001.p.6.

6. Ministry of Health Indonesia. Health Profile Indonesia 2000 (Indonesian). Jakarta: Ministry of Health Indonesia; 2000. p.106.

7. Utomo B, Suparno H, Siagian FP, Dharmaputra NG, Ismail A. Behaviour of intravenous drug users and threatened of HIV/AIDS epidemic : surveillance in Jakarta year 2000 (Indonesian). Seminar of 13 years of HIV/AIDS, Jakarta Nov 22 2000.

8. Djoerban Z. Clinical profile of AIDS in Jakarta (Indonesian). J Indones Med Assoc 1997;47(1):19-24.

9. USPHS/IDSA Prevention of Opportunistic Infections Working Group. 1999 USPHS/IDSA guidelines for the prevention of opportunistic infections in persons infected with human immunodeficiency virus. Ann Intern Med 1999; 131(11): 873-900.

10. Kovacs JA, Masur H. Prophylaxis against opportunistic infections in patients with human immunodeficiency virus infection. New Eng J Med 2000; 342(19):1416-29.

11. Moylett EH, Shearer WT. HIV: Clinical manifestations. J Allergy Clin Immunol 2002; 110:3-16.

12. Chaisson RE, Benson CA. Tuberculosis and HIV infection. In : Rosman MD, MacGregor RR. Tuberculosis: Clinical and new challenges. New York: MacGrawHill Inc; 1995. p. 223-38.

13. Price RW. Management of the neurologic complications of HIV-1 infection and AIDS. In: Sande MA, Volberding PA (editors). Medical management of AIDS. Philadelphia: WB Saunders Co. 1999. p. 217-40. 